\title{
Spatial Correlation Analysis of Land Subsidence and The Water Table Changes in Unconfined Aquifers Using Sentinel 1-SAR Image and Geographic Information Systems (Case Study: Semarang City - Indonesia)
}

\author{
Hana Sugiastu Firdaus ${ }^{1, *}$, Yudo Prasetyo ${ }^{1}$, and Diyanah Diyanah ${ }^{1}$ \\ ${ }^{1}$ Department of Geodetic Engineering, Faculty of Engineering, Diponegoro University, Semarang - Indonesia
}

\begin{abstract}
Groundwater has a very important role both in terms of environmental, social and economic. The consumption of groundwater continuously can affect the physical condition of the environment such as land subsidence, especially in Semarang City. The spatial correlation of land subsidence and water table changes was analyzed in this study using remote sensing and geographic information systems. PS-InSAR method is used to process Sentinel-1 SAR image satellite to get the result of land subsidence during in 2014-2017. The annual average of vertical land subsidence in Semarang City, with the range $0 \pm 3.4 \mathrm{~cm}$ to $4.5 \pm 3.4$. The spatial relation between the land subsidence and the water table decreased is obtained using the rules of the spatial correlation matrix. The study area was dominated by a very high correlation with the percentage (47.58\%), which located in several areas in Genuk District, Tembalang District, Pedurungan District, Tugu District and Mijen District. The potential of groundwater in unconfined aquifers in Semarang City is nihil potential and low potential of groundwater quality. The very high correlation between land subsidence and water table decreased, which located in the low potential of groundwater in unconfined aquifer mostly located in Tembalang District.
\end{abstract}

Keywords: Aquifer ; Groundwater ; Land Subsidence; Sentinel-1; Spatial Correlation

\section{Introduction}

Groundwater is one of the essential human needs, that is located below the earth's surface and is stored in the geologic formations. In urban areas especially in Semarang city, the fulfillment of water consumption is mostly obtained from groundwater utilization. Generally, the groundwater that are mostly utilized by the people for various purposes located at the depth of 1-25 meters below the earth's surface and is the main source of clean water used as the fulfilment of human needs. The manufacture of a well is one of the efforts to obtain clean water with a depth less than 20 meters below the earth's surface and is generally found in layers of sand, gravel sand, tuffs and silts. Groundwater that derived from dig a well by some peoples, generally, located in a free aquifer or unconfined aquifer that is a closed aquifer impermeable layer, and has a watertable. Unconfined aquifer also known as a watertable aquifer and shallow groundwater, is bounded below by an aquiclude, but is not restricted by any confining layer above it. Its upper boundary is the watertable, which is free to rise and fall. Water in a well penetrating an unconfined aquifer is at atmospheric pressure and dose not rise above the watertable [1].

\footnotetext{
* Corresponding author: hana.firdaus@live.undip.ac.id
}

The consumption of groundwater in unconfined aquifer continuously can affect the physical condition of the environment such as land subsidence. The spatial relation between land subsidence and watertable changes in unconfined aquifer is described in this study using remote sensing technology and geographic information systems. A remote sensing technology has the ability to assess large areas in a short time and related with the typical climate of Indonesia that lies in a tropical area (intensity and extensive high cloud cover). Utilization of remote sensing technology in this study using Sentinel1A radar image processing with Interferometric Wide (IW) acquisition method and VV polarization which covering Semarang City. The image processing is used to obtain the result of vertical land subsidence during in 2014-2017. Selection of radar technology is one solution that is good for spatial mapping in land subsidence estimation. The method that was used to obtain the value of vertical land subsidence using PS-InSAR, the newest method in RADAR image satellite processing which is give a good accuracy and minimize decorellation effects [2].

Decrease of water table in unconfined aquifers, processed based on observations of observation wells in 2003 and 2016. Spatial analysis in GIS method is used to obtain spatial correlation of vertical land subsidence with 
decrease of water table using overlay method and correlation matix. There are several types of unconfined aquifers based on the quantity and quality of groundwater in the groundwater basin map. The results of this study to analyze the level of spatial correlation between the vertical land subsidence and the decrease of the water table located in several types of unconfined aquifers.

Several types of unconfined aquifer in study areas, indicate the potential condition of groundwater in each aquifer types. The analysis in each type of aquifer aims to determine the potential condition of groundwater that has a level of spatial correlation from low to high between the vertical land subsidence and the decrease of the water table. Semarang City is divided into two categories of areas based on groundwater basin map, which is the groundwater basin and not the groundwater basin. The groundwater basin area consist of several aquifers types that are classified based on groundwater quality and quantity.

\section{Data and Study Areas}

The data used in this study outlined consists of 3 types of data that is Sentinel 1-A SAR image satellite data, Water Table changes in unconfined aquifers and groundwater basin in Semarang City.

\subsection{Sentinel 1-A}

Sentinel data is provided by European Space Agency (ESA) and can be accessed and downloaded free of charge from their website [3]. In this study, Level-1 product with Interferometric Wide (IW) mode and VV polarization was used to obtain vertical land subsidence in Semarang City during in 2014-2017. Seven image satellite in 2014-2017 are used in processing and selected the best pair of images (master and slave). This stage aims to select the best image pair based on the small value of the main distance estimation and the value of the coherency model. Based on the results of the main distance estimation, the image satellite that used in this study is the image pair with time coverage of 11 July 2016 as (master) and 6 other imagery as (slave). Image processing of Sentinel 1-A using open source software ie SNAP Desktop, SNAPHU and Stamps.

\subsection{Water Table Changes in Unconfined Aquifers}

The water table changes in unconfined aquifers map in 2003-2016 based on ESDM and the results of monitoring observation wells in 2003 and 2016. The decrease of water table in unconfined aquifers is spatially obtained from the processing of spatial operations, that is the reduction of the spatial interpolation observation wells in 2016 with the spatial interpolation observation wells in 2003. The decrease of water table map in 2003-2016 in the Semarang City is classified into 4 levels, which is the decrease of water table $(<40 \%)$, $(40 \%-60 \%)$ water table decreased, $(60 \%$
$-80 \%)$ water table decreased, and decrease of water table $(>80 \%)$. Water table decreased in unconfined aquifers during 2003-2016 in the study areas, dominated by a decrease of water table $<40 \%$ with the coverage area $246.82 \mathrm{~km}^{2}$. Decrease of water table $>80 \%\left(78,43 \mathrm{~km}^{2}\right)$ mostly located in north of Semarang City and covered in several districts, which is Semarang Utara District, Genuk District, Semarang Timur District, Gayamsari District, Semarang Tengah District and Semarang Barat District.

\subsection{Groundwater Basin}

Groundwater Basin in Semarang City can be classified by two types of groundwater basin areas are as follows[4]:

a. Semarang-Demak Groundwater Basin

Semarang-Demak groundwater basin has an unconfined groundwater flow of 581.3 million $\left(\mathrm{m}^{3}\right)$ year and the amount of confined groundwater flow is 16.5 million $\left(\mathrm{m}^{3}\right)$ /year. Semarang City is dominated by Semarang-Demak groundwater basin, that is covering in several districts are Tugu District, Tembalang District, Genuk District, Ngaliyan District, Candisari District, Semarang Barat District, Semarang Timur District, Semarang Tengah District, Semarang Selatan District, Gayamsari District and part of Mijen District.

b. Semarang-Ungaran Groundwater Basin

Semarang-Ungaran groundwater basin has the amount of unconfined groundwater flow is 8.1 million meters cubic per year, located in Gunung Pati and the highlands in Ungaran

\section{Method}

\subsection{The Processing Stages}

The processing stages in this study can be seen in Fig.1. The stages in this study is the processing of land subsidence using the PS-InSAR method, then spatial correlated with spatial data of decreased water table in unconfined aquifers and analyzed with unconfined aquifer types in the study area.

The stages of the PS-InSAR processing is required seven images satellite in the same location and different of coverage acquisition times. The main distance estimation stages, as the determining stage of the 7 images satellite with the best baseline to determine the slave and the master images satellite. The co-registration stages done on both images and DEM SRTM to know the suitability of master image and slave images. Furthermore, the stage of interferogram process, filtering, and gamma export which aims to export the results of the processing in to the form of gamma. The next stage is StaMPS processing, that is Standford method for persistents scatterers which in this process there are phase unwrapping, loading data interferogram that have been held together, error estimation, the process of adjusment computation with iterations repeatedly and PS selection that is the process of selecting distributed points. 


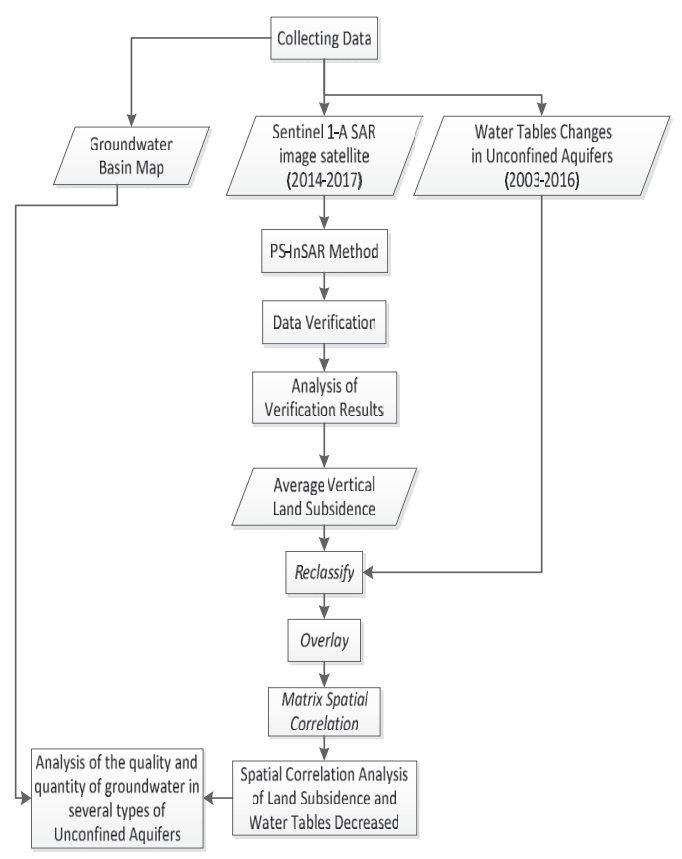

Fig. 1. The processing stages in this study

The results of the land subsidence is then correlated spatially with the decrease of water table in unconfined aquifers, which follows the correlation matrix rule shown in Table.1. Vertical land subsidence and the decrease of water table are classified into 4 categories, which are low, moderate, high and very high. The diagonal matrix from Table. 1 indicate a very high correlation between vertical land subsidence and the water table decreased with the score is (4). The correlation results, for further analysis will be spatial analyzed with the types of unconfined aquifer in study areas.

Table 1. Matrix Correlation of Land Subsidence and Decrease of Water Table

\begin{tabular}{|l|c|c|c|c|}
\hline $\begin{array}{c}\text { Land } \\
\text { Subsidence } \\
\text { Decrease of } \\
\text { Water Tables }\end{array}$ & Low & Moderate & High & $\begin{array}{c}\text { Very } \\
\text { High }\end{array}$ \\
\hline Low & 4 & 3 & 2 & 1 \\
\hline Moderate & 3 & 4 & 2 & 1 \\
\hline High & 1 & 2 & 4 & 3 \\
\hline Very High & 1 & 2 & 3 & 4 \\
\hline
\end{tabular}

\section{Result and Discussion}

\subsection{Land Subsidence}

PS-InSAR method is used to extract the results of vertical land subsidence in study areas. The results of Sentinel 1-A SAR images satellite processing with PSInSAR method, not only the average vertical land subsidence during 2014-2017, but also the average land subsidence corrected and standard deviation in each results of land subsidence. The average land subsidence is corrected with several parameters, such as DEM, orbital and atmosphere. The results of the processing are the average corrected land subsidence by DEM, orbital and atmospheric. The correction is aimed to get better processing result and in accordance same as with the actual condition in the field. The accuracy of the PSInSAR processing based on the calculation of standard deviation. The standard deviation from the seven (7) pairs of images satellite processings covered a whole of study areas.

The standard deviation of PS-InSAR processing shows the smallest distribution accuracy in the land subsidence average with atmospheric correction is 0.6. $21 \mathrm{~mm}$ and standard deviation of land subsidence average without correction, the minimum accuracy is 1.4 $\mathrm{mm}$ and the maximum accuracy is $42.4 \mathrm{~mm}$. The land subsidence average with DEM correction have the most value of standard deviation ia about 1.7 until $58.9 \mathrm{~mm}$.

The smaller of standard deviation value in processing indicated that the better of the level accuracy of land subsidence processing with PS-InSAR method. While the standard deviation value by orbital correction is about $0.9-20.6 \mathrm{~mm}$. Based on standard deviation value, the smallest standard deviation is the land subsidence average with atmospheric correction, but in this study, the results of land subsidence average with orbital correction is used to further analysis. Because of the land subsidence value by atmospheric correction are not accordance with the field conditions such as land subsidence in Gunung Pati District. This is the reason in this study using the result of orbital correction processing to define the land subsidence average in the study area. The value of land subsidence average with orbital correction can be seen in Fig. 2. Based on the results, the information of land subsidence average value in Semarang City maximum $-4.5 \pm 3.4 \mathrm{~cm}$ and maximum land surface increase of $2.4 \pm 3.4 \mathrm{~cm}$.

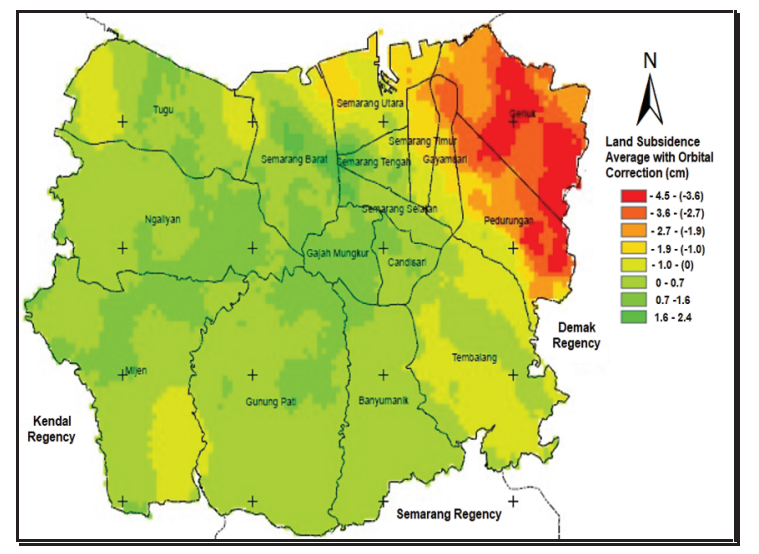

Fig. 2. Land Subsidence Average with Orbital Correction in Semarang City

The northern coastal area in the west of Semarang City has increased the land surface due to the unfilled points distribution of PS-InSAR in the area. The absence of PS-InSAR dots due to swaths in the area is unfilled by radar image satellite overlapping. The unfulfillment of the deformation point caused the interpolation in the northern coastal area in the west of Semarang City referring at the under point of deformation so in that coastal has increased of land surface. The land 
subsidence annual average value in this study by PSInSAR processing, with the range $0 \pm 3.4 \mathrm{~cm}$ to $4.5 \pm$ 3.4. The highest of land subsidence located in several district, such as Semarang Utara District, Semarang Barat District, Pedurungan District dan Genuk District.

Verification of PS-InSAR processing results using secondary data of annual land subsidence mean by GPS method from [5] Prasetya, et al (2017) research in 2016. The altitude data in 2016 combined with previous measurement study in 2013 and 2015 so as to obtain the rate of land subsidence from all data. Three (3) point observations from the results of these studies are used to verify the results of processing in this study. Based on the verification result using ground data by GPS method, there is a difference between ground data by GPS and PS-InSAR processing. The result of processing difference can be calculated by the RMSE value, where the smallest RMSE value is the result of land subsidence with orbital correction with RMSE $\pm 3.4 \mathrm{~cm}$.

\subsection{Spatial Correlation of Land Subsidence and Water Table Changes in Unconfined Aquifers}

The water table changes in this study is the result of water table decreased in unconfined aquifers during 2003-2016. There are four (4) categories of water table decreased that have been previously described in subsection 2.2. The category of water table decreased in this study be classified into four (4) classes and in each class has a category that according to the matrix correlation in table 1. The land subsidence average is also be classified into 4 classes, where the value range for each class based on the calculation of the maximum and minimum land subsidence value that divided by the number of classes. The value range and classification in each class for the water table decreased and the land subsidence average shown in Table 2.

Table 2. Classification of Land Subsidence and Water Table Changes in Unconfined Aquifers

\begin{tabular}{|c|c|c|}
\hline Category & $\begin{array}{c}\text { Land } \\
\text { Subsidence } \\
(\mathbf{c m})\end{array}$ & $\begin{array}{c}\text { Water Table Decreased } \\
\text { in Unconfined Aquifers }\end{array}$ \\
\hline Very High & $-3.3-(-4.5)$ & $\begin{array}{c}\text { decrease of water table } \\
(>80 \%)\end{array}$ \\
\hline High & $-2.2-(-3.3)$ & $\begin{array}{c}(60 \%-80 \%) \text { water table } \\
\text { decreased }\end{array}$ \\
\hline Moderate & $-1.1-(-2.2)$ & $\begin{array}{c}(40 \%-60 \%) \text { water table } \\
\text { decreased }\end{array}$ \\
\hline Low & $0-(-1.1)$ & $\begin{array}{c}\text { decrease of water table } \\
(<40 \%)\end{array}$ \\
\hline
\end{tabular}

The water table decreased in unconfined aquifers during in 2003-2016 in the Semarang City can be seen in Fig. 3. Based on the area calculation, the water table decreased that occurred in Semarang City is dominated by decrease of water table $(<40 \%)$, decrease of water table $(>80 \%),(40 \%-60 \%)$ water table decreased and $(60 \%-80 \%)$ water table decreased.

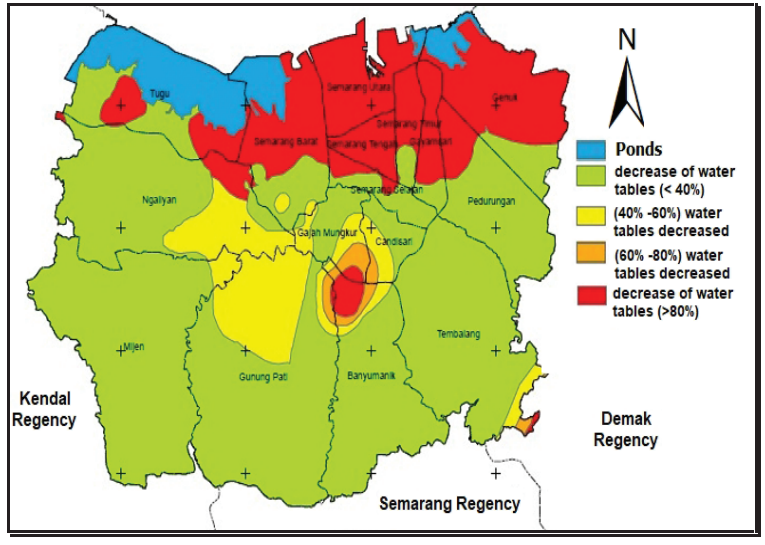

Fig. 3. The Water Table Decreased in Unconfined Aquifers (2003-2016)

The results of the spatial correlation of land subsidence and the water table changes in unconfined aquifers are shown in Fig.4. There are several areas in the study area that are not included in spatial correlation processings, such as ponds land cover and the areas which has increased land surface based on the results of land subsidence in this study. The result showed that the study area was dominated a very high correlation with percentage $(47.58 \%)$, low correlation with percentage (20.02\%), high correlation with percentage (16.29\%), and medium correlation with percentage (16.09\%).

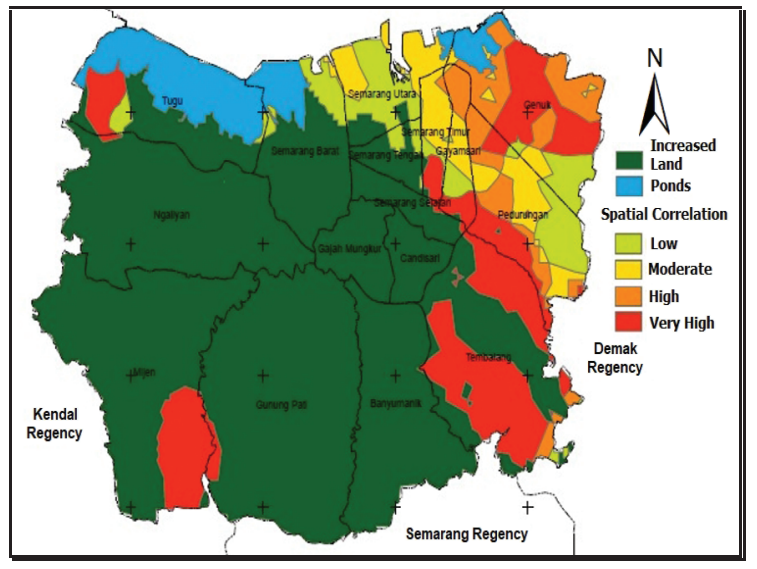

Fig. 4. Spatial Correlation of Land Subsidence and The Water Table Changes in Unconfined Aquifers

The very high spatial correlation lies in several district in Semarang City based on Fig.4, such as Genuk District, Tembalang District, Pedurungan District, Tugu District and Mijen District. A very high correlation indicates that the higher of land subsidence also the higher of water table decreased, and the lower of land subsidence also the lower of water table decreased. This shows that a very strong correlation between water table changes and land subsidence changes in several district in Semarang City. Land subsidence is not always caused by a water table decreased, but there are other factors that affect it such as disasters and else. Moderate and low spatial correlations occurring in some districts in Semarang City, which indicate that the land subsidence changes is not directly affected by water table changes. 


\subsection{Analysis of Type Aquifers and Groundwater Potential}

There are two types of aquifers, the unconfined aquifers and the confined aquifers. The unconfined aquifers is the focused aquifer that will be analyzed in this study. The distance below earth surface not too far in unconfined aquifers, with a depth less than 25 meters, compared the confined aquifers. The classification of unconfined and confined aquifers is based on the quality and quantity of groundwater, which indicating the groundwater potential. The classes of aquifer in Semarang City can be classified into five (5) types of aquifer, if based on the condition of unconfined aquifer and confined aquifer in the same location, as seen in Fig.6. If the groundwater quality in aquifer is bad, it can be assumed that there is no potential groundwater in the area (nihil potential). The qualities include chemical parameters $(\mathrm{Cl}, \mathrm{NO} 3$, So4, $\mathrm{pH}$ and TDS).

The groundwater quantity depends on the purpose, such as use to drinking water, industry, agriculture and other purposes. The classification of aquifers can be divided into 3 classification are low, medium and high for the drinking water purpose. That classification based on optimum water discharge in each aquifers. The high potential of groundwater if the optimum water discharge (Qopt) > 10 liters / sec, medium potential of groundwater if the optimum water discharge (Qopt) between 2 to 10 liters / sec, while low potential of groundwater if the optimum water discharge (Qopt) $<2$ liters / sec [6].

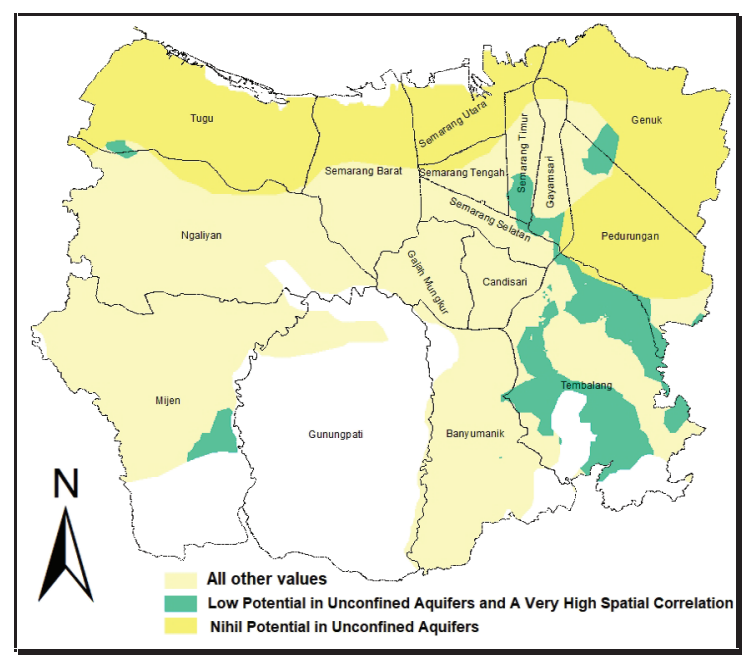

Fig. 5. Groundwater Potential in Unconfined Aquifers and A Very High Spatial Correlation between Land Subsidence and Water Table Decreased

The potential of groundwater in unconfined aquifers in Semarang City can be distinguished into two, nihil potential which shows no groundwater potential due to poor groundwater quality and low potential of groundwater quality with the optimum water discharge (Qopt) $<2$ liter / sec. The very high correlation between land subsidence and water table decreased, which is located in low potential of groundwater in unconfined aquifer can be seen in Fig.5, which is located mostly in Tembalang District. This can be an indicator that water table changes in the area caused optimum water discharge change due to the consumption of the groundwater to needs fulfilment, so it can affect the change in land subsidence. Nihil potential of groundwater in unconfined aquifers shows that poor groundwater quality to daily activities.

\section{Conclussion}

The value of land subsidence in an area can be obtained by the field measurement, and by radar image satellite processing by PS-InSAR method. The results of that processing is quite accurately with the implementation of efficient data processing, because the radar image satellite has a wide coverage area with the ability to penetrate the cloud. The vertical land subsidence in Semarang City in this study has result with the range $0 \pm$ $3.4 \mathrm{~cm}$ to $4.5 \pm 3.4$. The value is obtained from the average annual value of the vertical land subsidence, which has been corrected by orbital, where the standard deviation value is the result of verification processing with measurement data in the field and in accordance with existing field conditions. The spatial relation between the land subsidence and the water table decreased is obtained from the spatial processing by using the rules of the spatial correlation matrix. The result showed that the study area was dominated a very high correlation with percentage $(47.58 \%)$.

The very high spatial correlation located in several districts in study areas, such as Genuk District, Tembalang District, Pedurungan District, tugu District and Mijen District. The very high correlation between land subsidence and water table decreased, which is located in low potential of groundwater in unconfined aquifer mostly located in Tembalang District. This can be an indicator that water table changes in the area caused optimum water discharge change due to the consumption of the groundwater to needs fulfilment, so it can affect the land subsidence.

\section{References}

1. A. G.P. Kruseman, N.A. de Ridder, Analysis and Evaluation of Pumping Test Data (International Institute for Land Reclamation and Improvement, The Netherlands, 2000)

2. Y. Prasetyo, S. Subiyanto, Jurnal Teknik (Jurnal Ilmiah Bidang Ilmu Kerekayasaan) Vol 35, 2 (2014)

3. ESA, Sentinel-1 SAR, ESA Sentinel online https://sentinel.esa.int/web/sentinel/userguides/sentinel-1-sar, accessed in 25 June 2017.

4. F. S. Zahra, T.T. Putranto, W. K. Hidajat. Jurnal Universitas Diponegoro (2016)

5. A. B. Prasetya, et al, Jurnal Geodesi UNDIP Vol 6, 2 (2017)

6. Panitia Teknik 96, geologi dan Sumber Daya Mineral. Penyelidikan potensi air tanah skala 1:100.000 atau lebih besar. SNI 13-7121-2005. (2005) 